\title{
Effects of Nitrogen, Phosphorus and Potassium Rates on Yield and Quality on Durum Wheat in a Two-year Rotation
}

\author{
Giovanna Cucci*, Giovanni Lacolla \\ Dipartimento di Scienze delle Produzioni Vegetali, Università di Bari \\ Via Amendola 165/A, 70126 Bari, Italy
}

Received: 24 February 2006. Accepted: 5 May 2006

\begin{abstract}
Within the environmental impact reduction perspective, this work was aimed at assessing for durum wheat, grown within two crop rotations, the minimum allowable value of fertilising formulae to obtain adequate crop yields and quality for the operators of the whole production chain. Six fertilising formulae $\mathrm{N}_{1} \mathrm{P}_{1} \mathrm{~K}_{1}, \mathrm{~N}_{1} \mathrm{P}_{2} \mathrm{~K}_{1}, \mathrm{~N}_{2} \mathrm{P}_{1} \mathrm{~K}_{1}, \mathrm{~N}_{2}$ $\mathrm{P}_{2} \mathrm{~K}_{1}, \mathrm{~N}_{3} \mathrm{P}_{1} \mathrm{~K}_{1}, \mathrm{~N}_{3} \mathrm{P}_{2} \mathrm{~K}_{1}$, obtained from the factorial combination of 3 nitrogen levels $(\mathrm{N}=50-100-150 \mathrm{~kg}$ ha-1) and 2 phosphorus rates $\left(\mathrm{P}_{2} \mathrm{O}_{5}=50-100 \mathrm{~kg} \mathrm{ha}^{-1}\right)$ were compared against an unfertilised control $\mathrm{N}_{0} \mathrm{P}_{0} \mathrm{~K}_{0}$. The potassium rate was the same for all fertilising formulae $\left(\mathrm{K}_{2} \mathrm{O}=100 \mathrm{~kg} \mathrm{ha}^{-1}\right)$. The treatments were studied within a comparative trial between 2 two-year rotations: potato - wheat + bean $\left(A_{1}\right)$ and potato + purslane - wheat + bean $\left(A_{2}\right)$ aimed at testing the purslane potential and its ability to use the available residual nitrogen after potato cropping to reduce deep percolation losses. The best yield results were observed for wheat in the rotation that did not include purslane after potato $\left(\mathrm{A}_{1}\right)$. In agreement with the literature, the nitrogen fertilisation had a positive effect on wheat grain yield also in the same cropping season as a consequence of a diversified action on the major yield components. The highest grain yields were observed in both rotations at the rate of $150 \mathrm{~kg} \mathrm{ha}^{-1}$ of $\mathrm{N}$, without any change with the rates of $\mathrm{P}$. The protein content, which is higher in rotation $\mathrm{A}_{1}$, shows in both rotations the lowest value in the unfertilised control and improves with the increase in fertilisation, reaching the highest value (about $6 \%$ more) with the rate $\mathrm{N}_{3}$. No significant difference was observed between the rates $\mathrm{N}_{1}$ and $\mathrm{N}_{2}$; this would suggest a lower efficiency of the latter, at least for protein accumulation. A similar trend was observed in the gluten content that does not show any significant difference between $\mathrm{N}_{0}$ and $\mathrm{N}_{1}$, whereas it shows increases significantly different with the two higher rates. The inclusion of purslane that could use the residual nitrogen after potato crop so as to reduce deep percolation losses seems to induce a significant reduction of all yield parameters of wheat crop. As to the effect of nitrogen fertilisation, an application of $100 \mathrm{~kg} \mathrm{ha}^{-1}$ is shown to produce a satisfactory yield response, but higher inputs of $\mathrm{N}\left(150 \mathrm{~kg} \mathrm{ha}^{-1}\right)$ are necessary to achieve good quality standards, at least in terms of protein and gluten content. As regards phosphorus fertilisation, the application of $50 \mathrm{~kg} \mathrm{ha}^{-1}$ of $\mathrm{P}_{2} \mathrm{O}_{5}$ is shown to produce a satisfactory response.
\end{abstract}

Key-words: durum wheat, fertilising formulae, quality aspects, crop rotation.

\section{Introduction}

The increased sensitivity to environmental protection and sustainable development issues calls for environmentally friendly cropping techniques aimed at the conservation and/or the improvement of non-renewable natural resources. This justifies the trend to reduce soil tillage for the beneficial effects on the organic matter content and on the structure stability, with the subsequent protection of the soil from water erosion; the identification of appropriate crop ro- tations for maintaining the physical and chemical soil fertility both for the useful effects on crop yields and on the sustainability of agro-systems; the reduction of nitrogen application rate to minimize environmental pollution and production costs. Contrary to nitrogen, excess in phosphorus has no consequence on crop yield. For these reasons it is necessary to reduce as more as possible nitrogen fertilisation and to identify the most appropriate nitrogen rate to apply to the crop without affecting the quanti- 
qualitative standards of production (Poma et al., 2001).

Nitrogen fertilisation combined with the use of more yielding genotypes has been one of the major factors to increase cereal yields. An improper use of this farming practice, however, may be particularly harmful both for the potential pollution of ground water resources by nitrates and for the high energy cost demanded by industrial production (Sequi and Antisari, 1989). This is leading to a reduced use of inputs, considering that in cereal crops the increase in the biomass subsequent to nitrogen fertilisation is not always associated with a proportional increase in grain yield. In durum wheat nitrogen also plays a crucial role to improve the grain technological properties (Desiderio et al., 1998). Nitrogen fertilisation induces an increase in the protein content (Fares et al., 1993; Borghi et al., 1997; Peckanek et al., 1997; Giuzio et al., 2005). In a study on the effect of nitrogen fertilisers on durum wheat, Wieser and Seilmeier (1998) observed a protein increase by $44-68 \%$. The high hectolitre weight and kernel size, influenced by environmental factors such as nitrogen fertilisation, are associated to the milling quality (Dexter et al., 1991; Novaro et al., 2001). Another factor that might negatively affect the semolina yield is the presence of yellow berries, caused by imbalances in nitrogen fertilisation. In studies conducted in Southern Italy areas characterized by typical durum wheat cultivation and low rainfall, the optimal nitrogen rate has been identified for this crop in the range between 60 and $100 \mathrm{~kg} \mathrm{ha}^{-1}$ (Caliandro et al., 1981; Maiorana et al., 1992; De Giorgio et al., 1993 and 1994; Flagella et al., 1997; Venezia et al., 2003; Poma et al., 2005). In a research conducted by Toderi et al. (2005) durum wheat showed a poor response to phospatic fertilisation: small amounts were sufficient, additional amounts increased the phosphorus content of products and by-products only. Potassium fertilisation did not show any significant effect, despite the moderate clay content $(27 \%)$ in the soil. Within the environmental impact reduction perspective, this work was aimed at assessing for durum wheat, grown within two crop rotations, the minimum allowable value of fertilising formulae to obtain adequate crop yields and quality for the operators of the whole production chain. Given the close relationships between ni- trogen levels, grain yield and carbon uptake (Van Keulen et al., 1988; Sinclair and Horie, 1989; Martin et al., 1990), the research was directed to studying the crop nitrogen status through the measurement of the leaf chlorophyll index.

\section{Materials and methods}

The research was conducted at the experimental field close to the Agricultural Faculty of Bari University (Italy), in plastic pots (h and $\varnothing$ of respectively 0.60 and $0.72 \mathrm{~m}$, equipped at the bottom with a tap to collect drainage water) filled with silty-clay soil of good fertility.

Six fertilising formulae $\mathrm{N}_{1} \mathrm{P}_{1} \mathrm{~K}_{1}, \mathrm{~N}_{1} \mathrm{P}_{2} \mathrm{~K}_{1}$, $\mathrm{N}_{2} \mathrm{P}_{1} \mathrm{~K}_{1}, \mathrm{~N}_{2} \mathrm{P}_{2} \mathrm{~K}_{1}, \mathrm{~N}_{3} \mathrm{P}_{1} \mathrm{~K}_{1}, \mathrm{~N}_{3} \mathrm{P}_{2} \mathrm{~K}_{1}$, obtained from the factorial combination of 3 nitrogen levels $\left(\mathrm{N}=50-100-150 \mathrm{~kg} \mathrm{ha}^{-1}\right)$ and 2 phosphorus rates $\left(\mathrm{P}_{2} \mathrm{O}_{5}=50-100 \mathrm{~kg} \mathrm{ha}^{-1}\right)$ were compared against an unfertilised control $\mathrm{N}_{0} \mathrm{P}_{0} \mathrm{~K}_{0}$. The potassium rate was the same for all fertilising formulae $\left(\mathrm{K}_{2} \mathrm{O}=100 \mathrm{~kg} \mathrm{ha}^{-1}\right)$.

The treatments were studied within a comparative trial between 2 two-year rotations: potato (Solanum tuberosum L.) - wheat (Triticum durum Desf.) + bean (Phaseolus vulgaris $\mathrm{L}$.) $\left(\mathrm{A}_{1}\right)$ and potato (Solanum tuberosum L.) + purslane (Portulaca oleracea L.) - wheat (Triticum durum Desf.) + bean (Phaseolus vulgaris $\mathrm{L}$.) $\left(\mathrm{A}_{2}\right)$ aimed at testing the purslane potential and its ability to use the available residual nitrogen after potato cropping to reduce deep percolation losses.

The split plot design with 2 replicates was used, with the rotations in large plots (14 containers) and fertilising formulae in single pots; fertilisers were applied in the pre-established amounts.

The "Colosseo" cultivar was sown on 28 November 2000 at a density corresponding to 400 seeds $\mathrm{m}^{-2}$ in rows spaced $0.20 \mathrm{~m}$. Phosphorus and potassium fertilisation was performed at pre-sowing (7 days prior to sowing), using mineral perphosphate and potassium sulphate respectively, whereas nitrogen fertiliser was applied as ammonium nitrate at seeding (1/3) and as top dressing $(2 / 3)$ in two applications with a 20-day interval.

During the cropping season, the crop was irrigated whenever the soil mass contained in the pot lost by evapotranspiration $50 \%$ of available 
Table 1. Effects of two crop rotations $\left(A_{1}\right.$ and $\left.A_{2}\right)$ on the yield parameters of durum wheat (cv. Colosseo).

\begin{tabular}{|c|c|c|}
\hline \multirow[t]{2}{*}{ Yield parameters } & \multicolumn{2}{|c|}{ Crop rotations } \\
\hline & $\mathrm{A}_{1}$ & $\mathrm{~A}_{2}$ \\
\hline Tillering rate & $1.4 \mathrm{~A}$ & $1.3 \mathrm{~B}$ \\
\hline Plant height $(\mathrm{m})$ & $0.67 \mathrm{~B}$ & $0.68 \mathrm{~A}$ \\
\hline Ears $\left(\mathrm{n} \mathrm{pot}^{-1}\right)$ & $189.5 B$ & $187.1 \mathrm{~A}$ \\
\hline Seed yield $\left(\mathrm{g} \mathrm{pot}^{-1}\right)$ & $289.9 \mathrm{~A}$ & $243.3 B$ \\
\hline Shoot dry biomass $\left(\mathrm{g} \mathrm{pot}^{-1}\right)$ & $823.2 \mathrm{~A}$ & 698.2B \\
\hline Hectolitre weight $\left(\mathrm{kg} \mathrm{hl}^{-1}\right)$ & $81.4 \mathrm{~A}$ & $80.6 \mathrm{~B}$ \\
\hline 1000 seed weight $(\mathrm{g})$ & $55.8 \mathrm{~A}$ & $53.2 \mathrm{~B}$ \\
\hline Non-vitreous kernels (\%) & $24.1 \mathrm{~B}$ & $27.2 \mathrm{~A}$ \\
\hline Protein $(\%)$ & $12.1 \mathrm{~A}$ & $11.4 \mathrm{~B}$ \\
\hline Gluten (\%) & $9.8 \mathrm{~A}$ & $8.4 \mathrm{~B}$ \\
\hline SPAD values & $39.0 \mathrm{~A}$ & $35.1 \mathrm{~B}$ \\
\hline
\end{tabular}

For each effect considered, the values followed by the same letter are not significantly different, according to the SNK test at $\mathrm{P} \leq 0.01$

water; the applied watering volume was that required to restore field capacity. Treatments against mildew and eyespot were also applied. All the farming practices used in the area (Apulia, Italy) were adopted. Moreover, at late flowering (14 May 2001) the flag leaf was tested for the chlorophyll index using the Chlorophyll Meter, SPAD-502, Minolta with a view to characterise the crop nitrogen status.

At harvest, performed on July 2nd 2001, at full grain ripening, each experimental unit (pot) was tested for the tillering rate, plant height and dry matter, and for the main yield components (number of ears and kernel yield). The grain samples taken at harvest were then tested for the following quality analyses: hectolitre weight and 1000 seed weight; percentage of yellow berries by visual inspection of a 50 -seed sample; determination of the nitrogen percent content
(Kjeldhal method) and the subsequent protein content ( $\%$ of dry matter) in wholemeal flour; gluten content ( $\%$ of dry matter) in wholemeal flour, following the AACC standards (1983, method 38-10).

All data were then submitted to the analysis of variance using the SAS software (SAS Institute Inc. USA), and the differences between the means were assessed by Student-NewmanKeuls' SNK test.

\section{Results and discussion}

The analysis of variance has revealed significant differences subsequent to the preceding crop on all tested parameters except the plant height and the number of ears per pot.

The best yield results were observed for wheat in the rotation that did not include purslane after potato $\left(A_{1}\right)$, most likely because of a greater nitrogen supply throughout the cropping cycle (Tab. 1).

Although in the two crops, the parameters under study showed different values as related to the different preceding crop, the results obtained showed a similar pattern without any interaction with the change in fertilizing formulae. In both rotations the crop was more luxuriant as the nitrogen fertilising level increased; the lowest tillering rate (1.2) was observed for the unfertilised control, whereas the highest one (1.4) was found for the crops fertilised by the formula $\mathrm{N}_{2} \mathrm{P}_{2} \mathrm{~K}_{1}$ without further increases with growing nitrogen rates (Tab. 2).

The plant height was also statistically different from the other treatments being compared, and showed definitely lower values $(0.56 \mathrm{~m})$ on-

Table 2. Effects of different fertilising formulae on the yield parameters of durum wheat (cv. Colosseo), cultivated within two crop rotations $\left(\mathrm{A}_{1}\right.$ and $\left.\mathrm{A}_{2}\right)$.

\begin{tabular}{lcccccccc}
\hline $\begin{array}{l}\text { Fertilization } \\
\text { formulae }\end{array}$ & \multicolumn{2}{c}{ Tillering } & rate & \multicolumn{2}{c}{ Plant height $(\mathrm{m})$} & Ears & (n pot $\left.{ }^{-1}\right)$ & \multicolumn{2}{c}{$\begin{array}{c}\text { Shoot dry biomass } \\
\left(\mathrm{g}^{\text {pot }}{ }^{-1}\right)\end{array}$} \\
\cline { 2 - 9 } & $\mathrm{A}_{1}$ & $\mathrm{~A}_{2}$ & $\mathrm{~A}_{1}$ & $\mathrm{~A}_{2}$ & $\mathrm{~A}_{1}$ & $\mathrm{~A}_{2}$ & $\mathrm{~A}_{1}$ & $\mathrm{~A}_{2}$ \\
\hline $\mathrm{N}_{0} \mathrm{P}_{0} \mathrm{~K}_{0}$ & $1.2 \mathrm{~B}$ & $1.2 \mathrm{C}$ & $0.56 \mathrm{~B}$ & $0.56 \mathrm{~B}$ & $172.0 \mathrm{C}$ & $169.0 \mathrm{D}$ & $282.0 \mathrm{D}$ & $239.0 \mathrm{D}$ \\
$\mathrm{N}_{1} \mathrm{P}_{1} \mathrm{~K}_{1}$ & $1.3 \mathrm{AB}$ & $1.3 \mathrm{~B}$ & $0.65 \mathrm{~A}$ & $0.65 \mathrm{AB}$ & $184.0 \mathrm{~B}$ & $176.0 \mathrm{CD}$ & $727.0 \mathrm{C}$ & $547.0 \mathrm{C}$ \\
$\mathrm{N}_{1} \mathrm{P}_{2} \mathrm{~K}_{1}$ & $1.3 \mathrm{AB}$ & $1.3 \mathrm{~B}$ & $0.71 \mathrm{~A}$ & $0.63 \mathrm{AB}$ & $185.3 \mathrm{~B}$ & $179.5 \mathrm{CD}$ & $763.0 \mathrm{C}$ & $564.7 \mathrm{C}$ \\
$\mathrm{N}_{2} \mathrm{P}_{1} \mathrm{~K}_{1}$ & $1.4 \mathrm{~A}$ & $1.3 \mathrm{~B}$ & $0.67 \mathrm{~A}$ & $0.71 \mathrm{~A}$ & $188.7 \mathrm{AB}$ & $187.0 \mathrm{BC}$ & $858.7 \mathrm{~B}$ & $764.0 \mathrm{~B}$ \\
$\mathrm{~N}_{2} \mathrm{P}_{2} \mathrm{~K}_{1}$ & $1.4 \mathrm{~A}$ & $1.4 \mathrm{~A}$ & $0.67 \mathrm{~A}$ & $0.74 \mathrm{~A}$ & $194.0 \mathrm{AB}$ & $192.2 \mathrm{AB}$ & $889.8 \mathrm{~B}$ & $783.3 \mathrm{~B}$ \\
$\mathrm{~N}_{3} \mathrm{P}_{1} \mathrm{~K}_{1}$ & $1.4 \mathrm{~A}$ & $1.4 \mathrm{~A}$ & $0.66 \mathrm{~A}$ & $0.70 \mathrm{~A}$ & $197.2 \mathrm{~A}$ & $202.0 \mathrm{~A}$ & $980.8 \mathrm{~A}$ & $889.5 \mathrm{~A}$ \\
$\mathrm{~N}_{3} \mathrm{P}_{2} \mathrm{~K}_{1}$ & $1.4 \mathrm{~A}$ & $1.4 \mathrm{~A}$ & $0.66 \mathrm{~A}$ & $0.71 \mathrm{~A}$ & $196.5 \mathrm{~A}$ & $195.0 \mathrm{AB}$ & $990.3 \mathrm{~A}$ & $870.0 \mathrm{~A}$ \\
\hline
\end{tabular}

For each effect considered, the values followed by the same letter are not significantly different, according to the SNK test at $\mathrm{P} \leq 0.01$. 


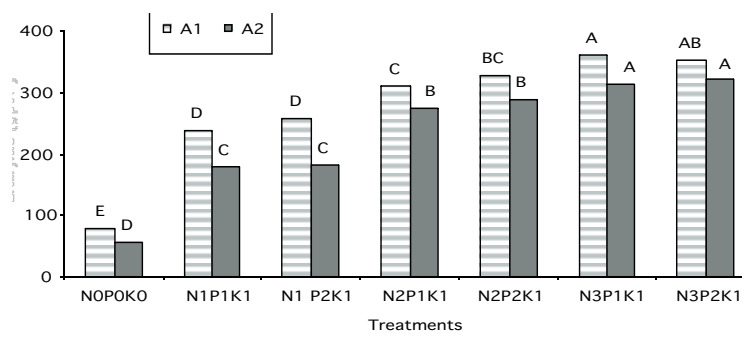

Figure 1. Effects of different fertilising formulae on the grain yield of durum wheat cultivated within 2 crop rotations. For each effect considered, the values followed by the same letter are not significantly different, according to the SNK test at $\mathrm{P} \leq 0.01$.

ly in the unfertilised control (Tab. 2). The fertilising level generally had a significant effect with a subsequently positive trend for all tested parameters. The number of ears per pot and the number of kernels per ear were on average higher for the treatment $\mathrm{N}_{3} \mathrm{P}_{1} \mathrm{~K}_{1}$, without deviating significantly from $\mathrm{N}_{3} \mathrm{P}_{2} \mathrm{~K}_{1}$ (Tab. 2). The increase in nitrogen fertilisation induced a higher shoot dry matter production that was, how-
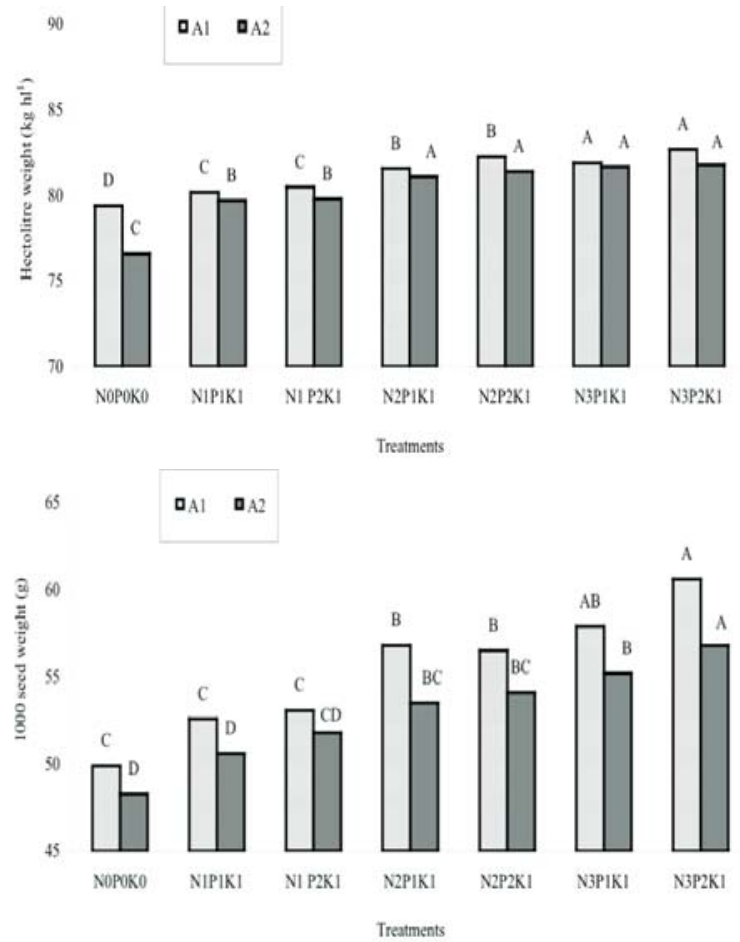

Figure 2. Effects of different fertilising formulae on the hectolitre weight and on the 1000 seed weight of durum wheat cultivated within 2 rotations. For each effect considered, the values followed by the same letter are not significantly different, according to the SNK test at $\mathrm{P} \leq 0.01$. ever, not statistically different between the two phosphorus levels (Tab. 2). In agreement with the literature, the nitrogen fertilisation had a positive effect on wheat grain yield also in the same cropping season (Giardini et al., 1980; Borin and Ceccon, 1987; Zentner and Campbell, 1988) as a consequence of a diversified action on the major yield components (Govi et al., 1981; Costantini and Boschi, 1987; Flagella et al., 1997). The highest grain yields were observed in both rotations at the rate of $150 \mathrm{~kg} \mathrm{ha}^{-1}$ of $\mathrm{N}$, without any change with the rates of $\mathrm{P}$. In a research conducted by Toderi et al. (2005), on durum wheat in a calcareous soil, it resulted that the lack of phosphatic fertilisation for over twenty years and the subsequent impoverishment of the soil in available phosphorus have caused such wheat yield losses $\left(0.2 \mathrm{t} \mathrm{ha}^{-1}\right)$ that do not to justify the fertilisation, and in any case, the rate of $50 \mathrm{~kg} \mathrm{ha}^{-1}$ was sufficient.

The results on the minimum $\mathrm{N}$ level that can provide satisfactory yield responses are also in agreement with the literature. Actually, in the trial conducted and in both rotations, an application of $50 \mathrm{~kg} \mathrm{ha}^{-1}$ of $\mathrm{N}$ resulted in a considerable yield increase (three times higher than the unfertilised control); further increases were obtained at the rates $\mathrm{N}_{2}$ and $\mathrm{N}_{3}$, equalling, respectively, $28.8 \%$ and $11.6 \%$ for rotation $\mathrm{A}_{1}$ and $54.8 \%$ and $13.2 \%$ for rotation $\mathrm{A}_{2}$ (Fig. 1).

The applied watering regime and the specific conditions recorded in the year, characterised by a low rainfall in autumn-winter months, might have favoured the crop potential to benefit from nitrogen fertilisation. The statistical analysis has shown that all quality indices are influenced by the rotation and by $\mathrm{N}$ rates; no influence was observed in the case of phosphorus fertilisation. The best results, in any case, have been recorded for the wheat crop in the rotation $A_{1}$. As to nitrogen fertilisation, the hectolitre weight and the 1000 seed weight were shown to increase with the $\mathrm{N}$ rate (Fig. 2); the percentage of non vitreous kernels decreased, instead, significantly with the increase in fertilisation, dropping respectively for rotations $A_{1}$ and $\mathrm{A}_{2}$ from 32.5 to 37.5 of the unfertilised control to 11 and 14.7 of the more fertilised treatment (Fig. 3).

The protein content, which is higher in rotation $\mathrm{A}_{1}$, shows in both rotations the lowest value in the unfertilised control and improves with 


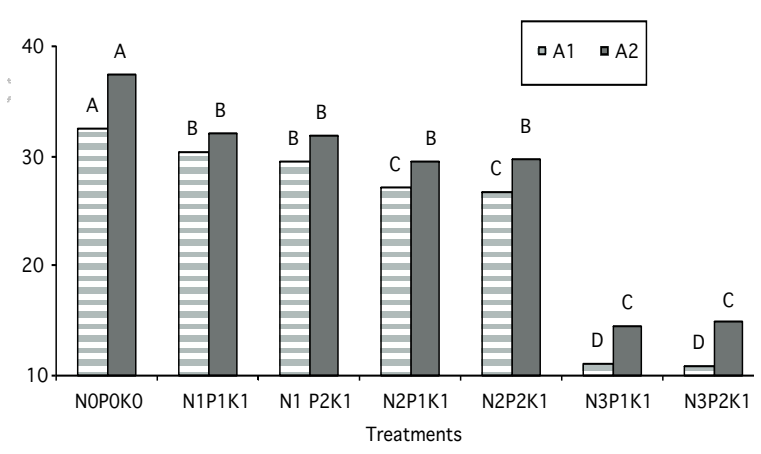

Figure 3. Effects of different fertilising formulae on the percentage of non vitreous kernels of durum wheat cultivated within 2 rotations. For each effect considered, the values followed by the same letter are not significantly different, according to the SNK test at $\mathrm{P} \leq 0.01$.

the increase in fertilisation, reaching the highest value (about $6 \%$ more) with the rate $\mathrm{N}_{3}$. No significant difference was observed between the rates $\mathrm{N}_{1}$ and $\mathrm{N}_{2}$; this would suggest a lower efficiency of the latter, at least for protein accumulation. The response of protein content to nitrogen rates reveals the inefficacy of nitrogen fertilisation at the lowest rates, whereas at the highest rates, its influence is very marked in accordance with the results observed by Santilocchi and Bianchelli (2003). A similar trend was observed in the gluten content that does not show any significant difference between $\mathrm{N}_{0}$ and $\mathrm{N}_{1}$, whereas it shows increases significantly different with the two higher rates (Fig. 4).

A significant effect of the rotations and of $\mathrm{N}$ application rates was observed on the SPAD index, which resulted to be closely correlated with grain yields (Fig. 5). In agreement with the literature, low SPAD values reflect a low $\mathrm{N}$ concentration in the leaves and a subsequent moderate photosynthetic ability (Miceli and Tassan Mazzocco, 2001).

\section{Conclusions}

Based on the results obtained on the effects of different fertilising formulae on durum wheat in 2 crop rotations the following conclusions may be drawn:

- the inclusion of purslane that could use the residual nitrogen after potato crop so as to reduce deep percolation losses seems to induce a significant reduction of all yield parameters of wheat crop;
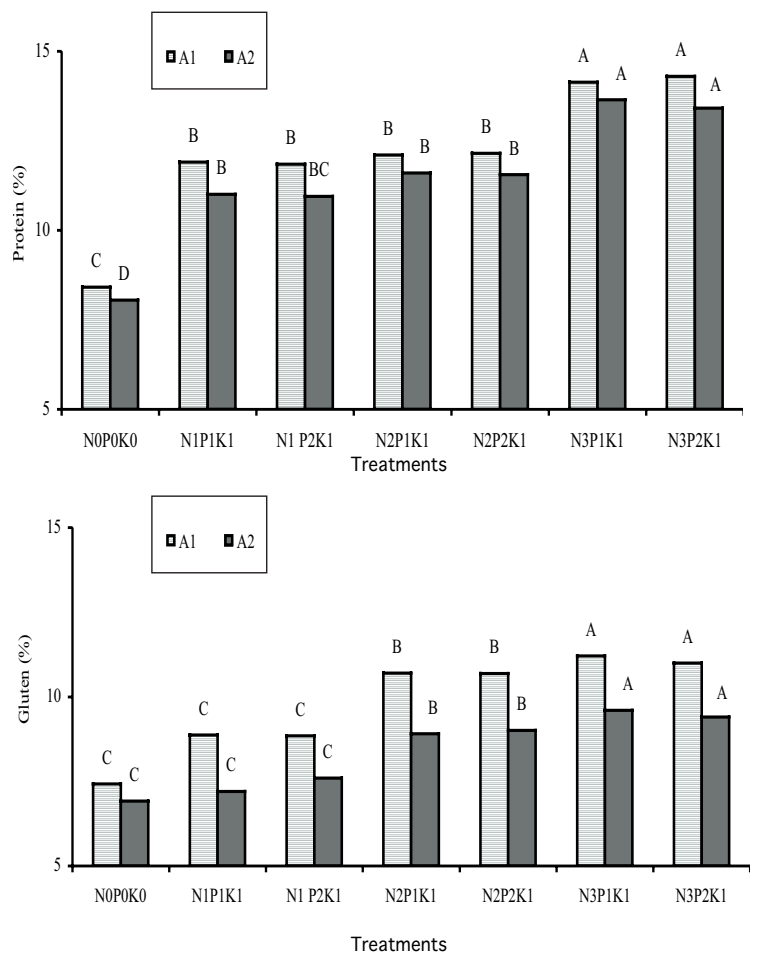

Figure 4. Effects of different fertilising formulae on the protein and gluten content of durum wheat cultivated within 2 rotations. For each effect considered, the values followed by the same letter are not significantly different, according to the $\mathrm{SNK}$ test at $\mathrm{P} \leq 0.01$.

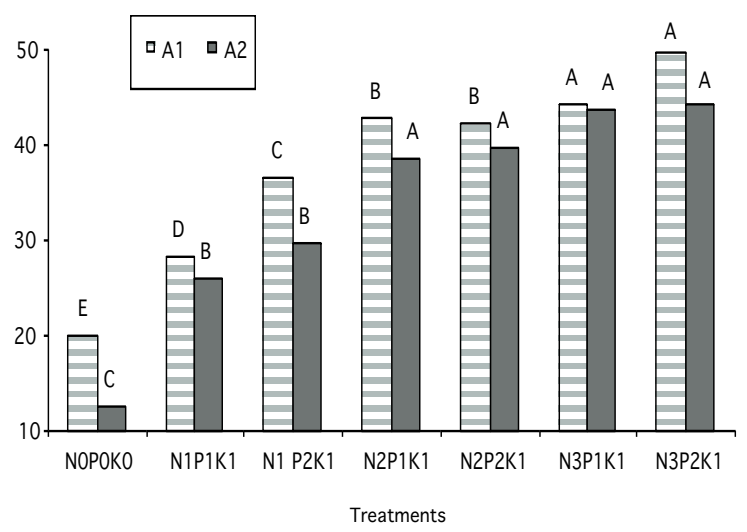

Figure 5. Effects of different fertilising formulae on the SPAD index of durum wheat cultivated within 2 rotations. For each effect considered, the values followed by the same letter are not significantly different, according to the SNK test at $\mathrm{P} \leq 0.01$.

- as to the effect of nitrogen fertilisation, an application of $100 \mathrm{~kg} \mathrm{ha}^{-1}$ is shown to produce a satisfactory yield response, but higher inputs of $\mathrm{N}\left(150 \mathrm{~kg} \mathrm{ha}^{-1}\right)$ are necessary to 
achieve good quality standards, at least in terms of protein and gluten content;

- as regards phosphorus fertilisation, the application of $50 \mathrm{~kg} \mathrm{ha}^{-1}$ of $\mathrm{P}_{2} \mathrm{O}_{5}$ is shown to produce a satisfactory response;

- the SPAD index of the most light-exposed leaf is always correlated to the grain yield.

\section{References}

Borghi B., Corbellini M., Minoia C., Palombo M., Di Fonzo N., Perenzin M. 1997. Effects of Mediterranean climate on wheat bread-making quality. European J. Agr., 6:145-154.

Borin M., Ceccon P. 1987. Influenza della concimazione organica e minerale sulla produzione del frumento tenero in tre tipi di terreno. Analisi del periodo 19641984. Riv. Agron., 21:269-274.

Caliandro A., Cavazza L., Mani V., Pacucci G. 1981. Effect of high nitrogen fertilizer levels on wheat in a mediterranean climate. Riv. Agron., 15:237-244.

Costantini E.A., Boschi V. 1987. Confronto tra ordinamenti cerealicolo-industriali su terreni argillosi padani. II. Comportamento morfo-fisiologico delle colture, componenti della resa e qualità tecnologiche dei prodotti. Genio Rurale, 11:13-28.

De Giorgio D., Rinaldi M., Rizzo V. 1994. Analisi dell'accrescimento, efficienza di utilizzazione dell'energia luminosa e produzione di cultivar di frumento duro (Triticum durum Desf.) concimate con dosi crescenti di azoto. Riv. Agron., 28:170-178.

De Giorgio D., Rizzo V., Rinaldi M. 1993. Dinamica dell'accrescimento del frumento duro (Triticum durum Desf.) in monosuccessione, sottoposto a differenti modalità di lavorazioni del terreno e dosi di fertilizzante azotato. Riv. di Agron., 27:524-531.

Desiderio E., D’Egidio M.G., Ciriciofolo E., Codoni D., Ledini M., Palumbo M., Porfici O., Fornaia M., Cecchini C. 1998. Effetti della concimazione azotata su produzione e qualità della granella di frumento duro. L'Inf. Agr., 54:31-38.

Dexter J.E., Tkachuck R., Typples K.H. 1991. Physical properties and processing quality of durum wheat fraction recovered from a specific gravity Tab. Cereal Chemistry, 68:401-404.

Dubetz S. 1977. Effect of high rates of nitrogen on Newpawa wheat grown under irrigation. I. Yield and protein content. J. of Plant Sci., 57:331-336.

Fares C., Paoletta G., De Ninno M., Gallo, A., Sorrentino G., Di Fonzo N. 1993. Effetti della concimazione azotata e dell'irrigazione sulla qualità tecnologica del frumento duro (Triticum durum Desf.) in ambienti con carenza idrica. Riv. di Agron., 27:117-124.

Giardini L., Giovanardi R., Toniolo L. 1980. Etude de la fertilisation et de l'irrigation en rotations culturales de Venetie. Contribution IV Aspects principaux de la productivité entre 1964 et 1975. Seminaire CEE Agrimed, Toulouse, 7-9 may, 82-98.

Flagella Z., Fares C., Stoppelli M.C., Vittozzi L.C., Cucci G., De Caro A. 1997. Effetto di bassi livelli di concimazione azotata sugli aspetti quanti-qualitativi del frumento duro (Triticum durum Desf.). Riv. Agron., 31:571-579.

Giuzio L., Giuliani M.M., La Rotonda P., Ciciretti L., De Caro A. 2005. Effetti di azoto e irrigazione su frumento duro. L'Inf. Agr., 7:45-48.

Govi G., Giordani G., Toderi G. 1981. Analysis of the yield components of wheat under different conditions of crop rotation and fertilization. Seminaire CEE Agrimed, Bari, 30 september - 2 october, 163-183.

Maiorana M., Convertini G., Di Bari V., Rizzo V. 1992. Yield and quality of durum wheat (Triticum durum Desf.) under continuous cropping after fine years of straw incorporation. Eur. J. Agron., 1:11-19.

Martin M., Miceli F., Mosca G., Zerbi G. 1990. Influence of nitrogen level and timing of application on the yield of winter wheat varieties. Agr. Med., 120:129137.

Miceli F., Tassan Mazzocco V. 2001. Aspetti predittivi delle rese mediante l'idice di clorofilla fogliare in frumenti a diverso apporto di azoto. XXXIV Convegno SIA, 111-112.

Novaro P., Colucci F., Venora G., D’Egidio M.G. 2001. Image analysis of whole grains: a noninvive method to predict semolina yield in durum wheat. Cereal Chemistry, 78:217-221.

Peckanek U., Karger A., Groger S., Charvat B., Schoggl G., Lelley T. 1997. Effect of nitrogen fertilization on quantity of flour protein components, dough properties, and breadmaking quality of wheat. Cereal Chemistry, 74:800-805.

Poma I., Gristina L., Noto F., Venezia G., Sarno M. 2001. Effetti della concimazione azotata e della precessione colturale sulla risposta bioagronomica e qualitativa di due genotipi di frumento duro. XXXIV Convegno SIA, 125-126.

Poma I., Randazzo B., Gristina L., Saladino S., Venezia G. 2005. Ruolo della precessione colturale, della concimazione azotata e del genotipo sulla risposta produttiva e qualitativa del frumento duro in ambiente mediterraneo. XXXVI Convegno SIA, 350-351.

Santilocchi R., Bianchelli M. 2003. Caratteristiche qualitative della granella di frumento duro (Triticum $d u$ rum Desf.) in relazione alla concimazione azotata. XXXV Convegno SIA, 315-316.

Sequi P., Antisari L.V. 1989. Dinamismo chimico dell'azoto. Aspetti agronomici e ambientali. Riv. Agron., 23:30-42.

Sinclair T.R., Horie T. 1989. Leaf nitrogen, photosynthesis and crop radiation use efficiency: a review. Crop Science, 29:90-98.

Toderi G., Giordani G., Tribeti L., Comellini F. 2005. Risultati sulla concimazione fosfatica e potassica ot- 
tenuti da esperienze di lunga durata. XXXVI Convegno SIA, 107-108.

Van Keulen H., Goudrian J., Seligman N.G. 1988. Modelling the effect of nitrogen on canopy development and crop growth. In: Russell G., Marshall B., Jarvis P.G. (eds.): Plant Canopies: their Growth, Form and Function. SEB Seminar Series, 31, 83-102.

Venezia G., Saladino S., Poma I., Ferrotti F., Gristina L., Noto F. 2003. Effetti della concimazione azotata e dell'avvicendamento colturale sulla traslocazione dell'azoto in quattro varietà di frumento duro. XXXV Convegno SIA, 189-190.

Wieser H., Seilmeier W. 1998. The influence of nitrogen fertilization on quantities and proportions of different protein types in wheat flour. Journal of the Science of Food and Agriculture, 76:49-55.

Zentner R.P., Campbell C.A. 1988. First 18years of a long term crop rotation study in south western Saskatchewan. Yields, grain protein, and economic performance. Can. Plant Sci., 68:1-21. 